\title{
FDI and Economic Growth in the Central African Economic and Monetary Community (CEMAC) Countries: An Analysis of Seven Economic Indicators
}

\author{
Paul Sindze ${ }^{1}$, Phouthakannha Nantharath ${ }^{2} \&$ Eungoo Kang ${ }^{1}$ \\ ${ }^{1}$ DBA, Saint Mary’s University of Minnesota, Minneapolis, US \\ ${ }^{2}$ Fiscal Management, College of Local Administration, Khon Kaen University, Khon Kaen, Thailand \\ Correspondence: Eungoo Kang, DBA, Saint Mary’s University of Minnesota, Minneapolis, US. E-mail: \\ exkang14@smumn.edu
}

Received: August 30, 2020

Accepted: October 16, 2020

Online Published: December 24, 2020

doi:10.5430/ijfr.v12n1p1

URL: https://doi.org/10.5430/ijfr.v12n1p1

\begin{abstract}
Foreign Direct Investment (FDI) can help create jobs, reduce unemployment, improve world-class technology transfer, and grow countries' economies. During the past 10 years, FDI net inflows to the Central African Economic and Monetary Community (CEMAC) has highly fluctuated and remained below to the total amount reached in 2010. The focus of this research was to statistically analyze the mean difference for FDI net inflows, GDP per capita, natural resource rents, inflation rate, corruption index, trade openness index, rule of law index, and political stability index received in each CEMACs country. Paired t-test methodology was used to conduct the analysis. Data were collected from the World Bank Group database from 2007 to 2017. This research revealed that FDI net inflows decreased by an average of two billion dollars in CEMAC when conducting a mean-to-mean analysis from the recession period to the recovery period. The findings showed that FDI net inflows inversely affected the GDP per capita in Congo and Gabon. FDI net inflows may have contributed to the improvement of the GDP per capita in countries such as Cameroon, Chad, Central Africa Republic, and Equatorial Guinea. Researcher recommendation for continued study is a qualitative research using the same variables through the same periods in addition to year 2018. Improvement of economic policies, regulations and laws, as well as the digitalization of public funds management are also recommended to boost economic development and growth in the CEMAC region.
\end{abstract}

Keywords: FDI net inflows, economic growth, corruption, political stability, CEMAC

JEL Classification Code: DO11, O47, O53

\section{Introduction}

The Central African Economic and Monetary Community or CEMAC is an organization made up of Cameroon, Central Africa Republic, Chad, Congo, Equatorial Guinea, and Gabon. Since their independence in the 1960s, there has been a rampant economic stagnation and growing poverty in the region caused by both exogenous and endogenous factors. The population of the CEMAC region is estimated to be at least 50 million people, living for the most part with less than one dollar a day according to the World Bank poverty standard (World Bank, 2018a).

With a natural-resources-based and underdeveloped economy, CEMAC countries have relied for the most part on FDI inflows in the region. The history of FDI inflows in CEMAC countries can be traced from the colonization era by some European countries (Ngongang, 2012). During the past 2 decades, major investors in this region have been the United States of America, France, United Kingdom, China, and Italy (United Nations Conference on Trade and Development [UNCTAD], 2017).

In the CEMAC region, FDI net inflows highly fluctuate from year to year. This makes prevision very difficult, since multiple factors influence the decision-making process of investors. The CEMAC region has been attractive to FDI because of high oil production, trade openness, higher growth rates, human capital, and infrastructure (Avom \& Ongo Nkoa, 2013). In fact, crude oil and other natural resources have been the biggest drivers for FDI in the region. During 2015, FDI flows in CEMAC fell by $36 \%$, which corresponded to a decrease of $\$ 5.8$ billion U.S. (UNCTAD, 2016). In the Congo for example, FDI flow dropped to $\$ 1.5$ billion after an unusually high $\$ 5.5$ billion dollars 
recorded in 2014 (UNCTAD, 2016). However, the decline of FDI net inflows in the CEMAC cannot only be attributed to natural resources pricing drop since the economic landscape of each country composite of CEMAC presented some relevant and significant differences. The differences encompassed country-specific internal and external factors. As for internal elements, political instability (Central Africa Republic, Cameroon, Gabon, and Chad) may have caused major roadblocks to investors. External causes may have been international economic sanctions against countries such as Equatorial Guinea and Congo Republic, in which both heads of state were under investigations for public funds distortion in France (Human Rights Watch, 2017). For the CEMAC region, the FDI flow decline signaled that economy's stakeholders in the region should take actions that would help stabilize the trend and encourage actions that boost economic development through FDI inflows.

Therefore, knowing which factors had a deterring or attracting effect on FDI inflows to the CEMAC region is important. The purpose of this research was to examine if there was a mean difference between the gross domestic product (GDP) per capita, political stability index, inflation rate, natural resource rents, trade openness index, rule of law index, Corruption Perception Index, and the impacting effect from fluctuating FDI net inflows to the CEMAC member countries. Data used in this research are from 10 years periods, from 2007 to 2017. Due to non-availability of data for 2018 and 2019 were not covered by this research.

\section{Literature Review}

\subsection{Global Expectation of Foreign Direct Investment Effect in CEMAC}

There were extensive published research studies on the determinants of FDI in the Sub-Sahara Africa (SSA) and other emerging markets, but very few were focused on the CEMAC region. According to Moreira (2009), African nations' economies were largely dominated by natural and mineral resources. CEMAC countries' economies were under industrialized and relied for the most part on oil production, minerals, and other natural resources (Avom \& Ongo Nkoa, 2013), which constituted a type of resource-seeking FDI. Avom and Ongo Nkoa (2013) described that CEMAC countries were mostly attracted to MNCs because of natural resources, essentially by oil. CEMAC countries are classified in three income groups as per their gross national income (GNI) per capita in accordance with the World Development Indicators database (World Bank, 2018a). This classification is as follows: at the upper middle income are Equatorial Guinea and Gabon, with the GNI per capita of $\$ 3,996$ to $\$ 12,375$; at the lower middle income are Cameroon and Congo with the GNI per capita for GNI per capita of $\$ 1,026$ to $\$ 3,995$; and at the low income class are Central Africa Republic and Chad with GNI per capita of $\$ 1,025$ or less.

According to the Organization for Economic Co-operation and Development (OECD; 2008), inward FDI created job opportunities that led to wage increases. African Development Bank (BAD), in their 2018 annual report on CEMAC' countries, stated that, the number of people living on less than $\$ 1.90$ a day has dropped progressively in terms of percentage, from about 76\% in 1996 to $60 \%$ in 2013 (BAD, 2018). The transfer of resources also usually resulted in an inward movement of capital along with technological transfer, which ultimately impacted the population lifestyle and population living conditions. This was at least what was observed after World War II with the Marshall Plan in Europe (Silberman et al., 1996). The Marshall Plan was successful in Europe, since the plan had successfully contributed to develop manufacturing and industrialized most countries' participants. A similar program could also be negotiated by CEMAC's countries with their counterparts from industrialized countries to help develop the region and/or each country.

Similarly, FDI has a history of having a direct and lasting impact on the regular citizen in Chile (Rosenberg, 2012). Purchasing power and life standard of citizens can be improved through FDI. Unemployment rate, for example, can be decreased in a country while improving people's lives and their state of happiness because they can proudly be able to work, take care of themselves, and their families. Along with economic reforms and democratization, Chile was able to grow its economy by 6.6\% a year from 1985 to 2000 (Rosenberg, 2012). As reported in the OECD annual report, a successful FDI implementation and usage in the CEMAC economy can upgrade the existing technical processes while improving people's life standards considerably (OECD, 2008).

\subsection{Importance of FDI Inflows to CEMAC}

Through FDI inflows, local economies and the investors can mutually benefit from the activities of their interactions. FDI inflows can be a great enacting tool for regional microeconomic development in CEMAC, as it can help multinational corporations (MNCs) increase their market shares in diverse activities sectors, such as information technology and communication. In Cameroon for example, Orange mobile, Nextel, and Mobile Telephone Network Cameroon have expanded mobile telecommunication in almost the entire country, thus easing the burden of needing to communicate with relatives, friends, and business partners living in other locations in the country or abroad. Alfaro 
(2016) recognized the theoretical effect of FDI on local economy at the microeconomic level with the knowledge spillover, backward and forward linkages with local firms, the potential for technology transfer, new processes, improved managerial skills, employee training, and access to international production networks. In theory then, firms in the market all have the potential to increase productivity, create employment, help diversify exports, and transform the production structure of the economy by fueling growth and fostering development (Alfaro, 2016).

Another example of how MNCs and other investors can take advantage of the FDI inflows in emerging markets like the CEMAC region is the involvement of China in agricultural activities in the CEMAC. China is heavily investing all across the CEMAC region, taking advantage of bilateral agreements with local governments to increase the agricultural production of commodities such as rice, plantains, bananas, and beans at the industrial level, using very advanced agricultural tools, while most of the local residents still work in a rudimentary manner. According to the International Monetary Fund (IMF) (2018), China is the SSA's largest trading partner.

Human health, engineering, manufacturing, and business management sectors are still very limited and need to be improved. These are activities that could eventually help industrialize the region, but FDI inflows to CEMAC seem to be very marginal in that way. All these microeconomics actions can be translated at the national level and global level through macroeconomics indicators; for example, the GDP, the quality of life index, and the human capital index are examples of macroeconomics aggregates used to assess the state of a country' economic development.

\subsection{FDI and Economic Growth in CEMAC}

Ongo Nkoa (2013) studied the impact of FDI on economic growth in the CEMAC between 1980 and 2010, using the Solow model of economic growth. The study showed that the ratio of FDI in GDP of the CEMAC countries has been steady annually and increasing for the past 3 decades until 2010. Despite the high variability of FDI in a highly unstable environment with political crises and unstable raw materials prices, FDI had a positive impact on the growth in the CEMAC in part. This positive impact was due to human capital. According to Ongo Nkoa, an increase of $1 \%$ of FDI inflows enhanced a 35\% increase in economic growth for the period prior to 2011. However, this affirmation has not been investigated by other studies, nor this study.

This literature review indicated that FDI inflows in SSA, thus CEMAC, influenced human development capital, enhanced policies and regulations, contributed to the GDP growth through the ratio of FDI incorporated in the real GDP, and ultimately stimulated economic development of the region. In addition, it was noted that the West African Economic and Monetary Union (UEMOA), which shared a lot of similarities with the CEMAC region in terms of past colonial history, the currency, and official spoken language in usage, seemed to influence CEMAC attractiveness to FDI. A study on this competitive attractiveness between the two regions was completed by Ngongang (2012). Ngongang's study revealed that the FDI flowing in the UEMOA zone directly attracted FDI inflows in the CEMAC zone. These inflows improved the business environment in both regions. The real impact of FDI on economic growth in the CEMAC region had yet to be investigated. Both regions tended to attract the same type of FDI, therefore it will be competitive in the long run rather than being complementary (Ngongang, 2012). It was also recommended to pay close attention to the type of FDI flowing into each region. A research paper on the matter of FDI (resource or market seeking) was conducted by Asiedu (2013) using the system's generalized moment method estimator to estimate a linear dynamic panel data model and found that natural resources had an adverse effect on FDI. In addition, the FDI-resource increased even after controlling for the quality of institutions and other important determinants of FDI. Nantharath and Eungoo (2019) studied FDI and economic growth in Lao PDR found that trade openness and institutional quality are among key economic indicators that attracted FDI inflows and sustained long-term growth during the period 2002 to 2017. Bayraktar (2013) studied the changing direction of FDI from developed countries towards developing countries. The study investigated the link between FDI and ease of doing business indicators as one possible source of the changing direction of FDI. The data source was the World Bank's Doing Business database and covered the years from 2004 to 2010. Findings showed that countries that had better records of doing business tended to attract more FDI. Bayraktar concluded that a country can attract more FDI inflows by improving its ease of doing business indicators, especially for developing countries. Bayraktar's findings helped support the purpose of the current study, which was to assess the influence of FDI on FDI determinants selected for this research. Therefore, improving weak FDI determinants' rating in CEMAC may help increase the region attractiveness to foreign investments.

\subsection{FDI Determinants in SSA and CEMAC}

Traditionally, MNCs sought to move part or the entire share of its activities overseas for multiple reasons. Those reasons ranged from ownership to market share aimed at the profit maximization. The most common traditional factors researchers used as determining FDI inflows were (a) market size, (b) trade openness, (c) labor cost, (d) productivity, 
(e) political risks, (f) infrastructure, and (g) the rule of law (Biswas, 2002; Kahai, 1999). Previous studies in the SSA did not include all CEMAC countries because of data unavailability. Some macroeconomic data were not collected for most CEMAC countries for years, since 1960. Variables included in these studies had meaning and relevance to the CEMAC economic, social, and political landscape.

In the case of CEMAC, this research examines variables that deal with rule of law, country openness to trade, and access to funds. Those variables include (a) starting a business, (b) dealing with licenses, (c) employing workers, (d) registering property, (e) getting credit, (f) protecting investors, (g) paying taxes, (h) trading across borders, (i) enforcing contracts, and ( $\mathrm{j}$ ) closing a business. In fact, with restricted access on human and commodities exchange across borders, investing in another country is difficult (Morris \& Aziz, 2011).

\subsection{How the Research Fits Into the Existing Body of Research}

There have been very few FDI studies that were essentially focused on CEMAC. Among the few, the review of the literature revealed Dongmo, Ngongang (2012), and Ongo Nkoa (2013), whose published studies put emphasis on the CEMAC regions. In fact, the CEMAC region is set apart from other SSA region because of its colonial history, the shared currency, language, political landscape, economic potential, and its natural resource diversification (Ngongang, 2012). Moreover, CEMAC's economic system was inherited from the French's colonization in the 1960s. CEMAC's economic policies were shaped based on the policies elaborated and implemented by France during the colonization era and have undergone very little change.

Therefore, this research is hoped to fill the existing literature gap in FDI study in both SSA and CEMAC regions while helping stimulate economic research for better CEMAC economic development and growth. Most importantly, this research is expected to have advanced the scholar, in the sense that students and academic practitioners in the future will use this work to educate while reinforcing human ethical fitness in doing business. Governments and nonprofit organizations working to improve business practice in the region are also expected to take some interest in the outcomes of this study. This research work will help in the formulation and reshaping regulations and laws to ease the business climate in the CEMAC region.

The findings of this research will raise awareness on what factors or variables CEMAC's leaders can take actions to increase their capabilities to attract and retain quality FDI inflows necessary for regional economic development and growth and as well serve as a guide for potential investors who may be willing to invest in the CEMAC.

\section{Research Method and Data}

\subsection{Conceptual Framework for the Research}

The conceptual framework of this study presented FDI net inflows as needed tools to fight poverty, boost economic growth and development, and facilitate technology transfer to improve the learning curve of local constituents in CEMAC. In fact, having foreign investments in the local economy encompasses more than economic interest. FDI influences local political economy while shaping how governments and lawmakers developed policies, regulations, and implement them.

This conceptual framework focused on factors that the researcher thought could impact the CEMAC economy through FDI net inflows. FDI net inflows can create what Farole, Staritz, and Winkler (2014) called the FDI spillovers and the absorption capacity of local companies and the workforce. For the purpose of this study, qualitative variables were made quantifiable through the use of their yearly given index, while quantitative variables were their yearly given values. The FDI net inflows were conceptualized as defined in the Definition section.

\subsection{Descriptive Statistics}

Data subject to this analysis were collected from the World Bank database. Data were interpreted according to the expected sign given to each variable that denoted its effect on FDI net inflows. Qualitative variables were assigned a sign using an expected sign of FDI effect on the index. Those indexes were available through the World Bank database and available to the public. The data were investigated using two samples data. The first sample used 2007 as base year, with data from 2007 to 2012 for each country. The second sample used 2012 as the base year, with data from 2012 to 2017 for each country. Then, for each sample, the difference for each data per year and the base year for the sample was calculated for each period. Two samples for means were performed utilizing a Microsoft Excel spreadsheet. This research used a significance level of $\alpha \leq .05$ and used two-tailed tests for all tests. Paired $t$ tests were run by country for each indicator and for the whole CEMAC region using the sum of each indicator for all countries.

The base year for each period was chosen according to the major economic event happening at the time. Year 2007 was chosen as the base year for the first series of data because it marked the year directly prior the beginning of the latest 
Great Economic Recession, year 2008. The second set of data used 2012 as the base year, since this researcher considered 2012 as the year after the full recovery from recession recovery for most SSA countries. In fact, SSA countries, which included CEMAC region, continued to receive more FDI inflows in 2012, despite a less favorable environment in the rest of the global economy. Hence, data analysis was conducted on a 5-year period using 10-year data, which encompassed years of economic crisis and years of economic recovery.

\subsection{Quantitative Approach}

This study used mean difference test approach to assess the relationship between (a) GDP per capita, (b) political stability, (c) inflation rate, (d) natural resource rents, (e) trade openness, (f) rule of law, (g) corruption perception, and (h) FDI net inflows in CEMAC region. The time-series data were from a 10-years period from 2007 to 2017. GDP per capita is chosen as the indicator of growth and development because it accounts for the total dollar value of goods and services being produced by an economy over a certain period of time. One of the benefits of this method is that it made possible to generalize the results to other regions. Similar quantitative method was used for previous studies to describe similar phenomenon includes Asiedeu (2013), Ata and Arvas (2011), Dongmo (2006), Hussein and Callaway (2017), Lebens (2017), and Su and Liu (2016). More specifically, this study adapted technique applied by Asiedu (2013) in the analysis of the relationships between FDI, natural resources, and institutions.

Given the CEMAC macroeconomics and political variables, the researcher expected the sign for political stability, inflation rate, rule of law, and corruption perception to be negative, while a positive sign was expected for GDP per capita, trade openness, and total natural resource rents. The rationale was that, as a country became less stable, investors would be reluctant to invest in such countries. In the meantime, in a context of high inflation rate and absence of equity and fairness in enforcing existing law, investors would be unenthusiastic about making a long commitment in such country; therefore, deterring the ability of that country to attract and retain FDI or quality FDI that would have a meaningful impact on local economy. The researcher also expected that a high corruption index will deter foreign investors from investing in a country.

In contrast, high GDP per capita, high volume of natural resource and the openness of a country to foreign investor were assumed to attract FDI. Therefore, the researcher expected the sign of the latter to be positive. A positive or negative expected sign indicated whether that variable influenced positively or negatively the dependent variable outcomes. For example, a negative expected sign for political stability implied that FDI net inflows affected the rating and tended to deter investors from making investment into the CEMAC region.

\section{Analysis Technique: Paired t-Test}

This study used a paired t-test analysis technique to analyze and compare data mean differences. The paired t-test was initially posed as a hypothesis concerning the relationship among the dependent mean and independent variables means. Hence, the analysis method is the most widely used procedure for examining and comparing changes among data. In econometrics, paired t-test method is widely used to compare two sets of data.

In this study, we used a paired $t$ test to examine if there was a mean difference between the selected seven independent variables during the period of 2012-2017. The focus of this study was whether fluctuating FDI net inflows influenced independent variables means. A total of eight tests were conducted for each country using seven independent variables and each country's FDI net inflows for each period.

\section{Hypothesis Testing and Decision Rule}

The study rejected the null hypothesis if the result of the $\mathrm{p}$ value revealed that there was sufficient evidence to conclude that there was a significant linear relationship between tested variables. A p-value lower or equal to 0.05 was considered statistically significant at $95 \%$ confidence interval, while $\mathrm{p}$ value greater than 0.05 was considered not statistically significant at $95 \%$ confidence interval. For all p-values statistically significant, the interval of confidence around the mean was calculated the identified the acceptance range of variable mean within the confidence interval. Thus, the regression coefficient was significantly different from zero.

\subsection{Quantitative Analysis With Paired t-Test Process}

A total of 48 paired $t$ test were conducted. The testing process was the same for each country. The procedure for a paired sample $t$ test can be summed up in four steps. The symbols used are defined as follows:

$\mathrm{D}=$ the differences between two paired samples,

$d i=$ the ith observation in $\mathrm{D}$,

$\mathrm{n}=$ the sample size, 
$\bar{d}=$ the sample mean of the differences,

$\sigma=$ the sample standard deviation of the differences,

$\mathrm{T}=$ the critical value of a $\mathrm{t}$ distribution with $(\mathrm{n}-1)$ degrees of freedom,

$t=$ the $\mathrm{t}$ statistic (t-test statistic) for a paired sample $\mathrm{t}$ test, and

$p=$ the $p$ value (probability value) for the $\mathrm{t}$ statistic.

\subsection{Paired t Test Regression Results Analysis}

This study was completed using a regression analysis on seven independent variables and one dependent variable using Microsoft Excel spreadsheets. The regression analysis was chosen as the approach for this study because this method was designed to provide systematic information about a phenomenon (Lebens, 2017; Shields \& Rangarajan, 2013). In this case, the phenomenon was the assessment of (a) GDP per capita, (b) political stability index, (c) inflation rate, (d) natural resource rents, (e) trade openness index, (f) rule of law index, (g) Corruption Perception Index potentially impacted by FDI net inflows to the CEMAC region.

Each selected variable drove a specific question that was tested and analyzed through a null and alternative hypothesis. Regression analysis was used because it allowed an understanding about which among the independent variables were related to the dependent variable, and an exploration of the forms of these relationships. Ultimately, for the purpose of this study, paired t-test was appropriate, as it gave possibility to compare the mean value of the dependent variable to the mean values of one or more independent variables. Finally, regression analysis is one of the most important statistical techniques for business applications. Regression analysis is a statistical methodology that helps estimate the strength and direction of the relationship between two or more variables. The regression results showed whether there was or was not a difference in variables' means; therefore, if there was an existence of a relationship or not.

This design was also appropriate for this study because it allowed a comprehensive way to assess the relationship between the chosen independent variables and the dependent variable. A benefit of the quantitative research design of the study was that the results may be generalizable to other regions of the SSA or somewhere else in the world; a place that could be considering assessing similar factors that could deter or attract investors in their regions. Hence, this study had a research design in which more than one independent variable were compared to a single dependent variable. The statistical significance was determined by looking at the $p$ value. The $p$ value gave the probability of the observed test results under the null hypothesis. The lower the $\mathrm{p}$ value the lower the probability of obtaining a result that rejected the null hypothesis. Thus, a low p value indicated a decreased chance for the null hypothesis to be accepted. The researcher used the cutoff value for determining statistical significance at a value of 5\% (or .05).

\section{Result}

\subsection{Paired t Test for CEMAC Region as a Whole}

Combined data from all CEMACs countries and their paired $\mathrm{t}$ tests show that rule of law at $(5)=.87$ and $\mathrm{p}$ value $=.39$, trade openness $t(5)=.-1.19$ and $p$ value $=.30$, total natural resource rents $t(5)=.2 .49$ and $p$ value $=.07$ were not statistically significant, meaning that a fluctuation of FDI did not globally and not significantly affect the rating or value of the above variables. On the other hand, GDP per capita $t(5)=.3 .74$ and $\mathrm{p}$ value $=.02$, political stability $\mathrm{t}(5)$ $=.3 .45$ and $\mathrm{p}$ value $=.03$, control of corruption perception $\mathrm{t}(5)=.3 .43$ and $\mathrm{p}$ value $=.03$, and rule of law at $(5)=5.50$ and $\mathrm{p}$ value $=.01$ were significantly impacted by the fluctuation of FDI net inflows in the region as a whole. This means that as a general trend in the CEMAC region, FDI net inflows fluctuation affected how stakeholders perceived the region in terms of its political stability and risk of violence, the corruption practice by government's agents, and the chances of getting a fair application of existing laws in case of an issue. This significance for the GDP per capita meant that FDI net inflows directly affected the purchasing power of CEMAC residents during the period of consideration.

Therefore, at $95 \%$ confidence interval for the true mean, difference for indicators statistically significant at $\mathrm{p}<.05$ for the whole CEMAC region was GDP per capita true mean lies somewhere between negative $-\$ 3,450.51$ and $-\$-1,995.05$, meaning the purchasing power of CEMAC' residents globally had decreased during 2012-2017. Figure 22 illustrates the significance interval at 95\% confidence interval, the area under normal distribution. Figure 20 shows a normal distribution, with a mean of $-\$ 2,722.48$ and a standard deviation of $\$ 727.73$. The shaded area contains $95 \%$ of the area and extends from $-\$ 4,742.66$ and $-\$-702.30$, which is within 1.96 standard deviation of the mean. This figure shows $83.49 \%$ of the distribution is within one standard deviation of the mean.

Political stability true mean lies somewhere between -3.18 and -.34, meaning the region as a whole was still at high risk of violence and terrorism. Figure 21 illustrates the significance interval at 95\% confidence interval, the area under normal distribution. Figure 23 shows a normal distribution, with a mean of -1.76 and a standard deviation of 1.02 . The 
shaded area contains $95 \%$ of the area and extends from -3.18 to -.34 . This figure shows $83.61 \%$ of the distribution is within one standard deviation of the mean.

The control for corruption perception rating true mean lies somewhere between -1.28 and -.12, meaning the region was remained seeing as a highly corrupt. Figure 24 illustrates the significance interval at $95 \%$ confidence interval, the area under normal distribution.

Rule of law true mean lies somewhere between -.1.31 and -.43, meaning CEMAC countries were still not fair and equitable in enforcing existing laws. Figure 25 illustrates the significance interval at $95 \%$ confidence interval, the area under normal distribution. Figure 25 shows a normal distribution, with a mean of -0.15 and a standard deviation of 0.05 . The shaded area contains $95 \%$ of the area and extends from -.23 and -.07. This figure shows $89.04 \%$ of the distribution is within one standard deviation of the mean.

Table 1. Summary of paired t Test results of all combined indicators in Central African Economic and Monetary Community Region

\begin{tabular}{|c|c|c|c|c|c|c|c|c|}
\hline & FDI Net Inflows & $\begin{array}{l}\text { GDP per } \\
\text { Capita }\end{array}$ & $\begin{array}{l}\text { Inflation } \\
\text { Rate }\end{array}$ & $\begin{array}{l}\text { Trade } \\
\text { Openness }\end{array}$ & $\begin{array}{l}\text { Total natural } \\
\text { resource } \\
\text { rents }\end{array}$ & $\begin{array}{l}\text { Political } \\
\text { Stability }\end{array}$ & $\begin{array}{l}\text { Control } \\
\text { Corruption } \\
\text { Perception }\end{array}$ & $\begin{array}{l}\text { Rule } \\
\text { of law }\end{array}$ \\
\hline $\bar{d}$ & $1,981,915,598.73$ & $(16,334.86)$ & 11.66 & (15.61) & (42.51) & $(1.76)$ & $(0.70)$ & $(0.87)$ \\
\hline$t$ & 2.60 & $(3.74)$ & 0.87 & (1.19) & $(2.49)$ & $(3.45)$ & (3.43) & $(5.50)$ \\
\hline$p$ & 0.06 & $0.02 *$ & 0.39 & 0.30 & 0.07 & $0.03 *$ & $0.03 *$ & $0.01 *$ \\
\hline
\end{tabular}

Notes. ${ }^{*} p \leq .05$ indicates statistical significance. Parentheses indicate a negative number. $\bar{d}=$ sample mean; $\mathrm{t}$ value measures the size of the difference relative to the variation the sample data; $p$ value is a number between 0 and 1 and interpreted in the following way: A small $\mathrm{p}$ value (typically $\leq 0.05$ ) indicates strong evidence against the null hypothesis, so the null hypothesis is rejected

\subsection{Paired t Test for Foreign Direct Investment Net Inflows}

The last paired t test compared the FDI net inflows post-recession period 2012-2017 against the recession period 2007-2012 for each country, based on a trend analysis of data 2007-2017. Cameroon and Equatorial Guinea paired t tests were not significant, with respective values $t(5)=-1.46$ and -1.16 , and $p=.22$ and .31 . The $p$ values were greater than the alpha and the $t$ values were smaller than the critical value.

However, paired t-test results of FDI net inflows for Central Africa Republic, Chad, Congo, and Gabon were statistically significant, with $\mathrm{t}$ values greater than critical value, and $\mathrm{p}$ values smaller than the alpha. Therefore, at $95 \%$ confidence, the true mean of FDI net inflows lies somewhere respectively for Central Africa Republic between $-\$ 113825262.98$ and $-\$ 30,716,070$; Chad between $-\$ 1,733,356,594.30$ and $-\$ 482,395,914.46$; Congo between $\$ 1,010,613,249.53$ and $\$ 4,124,199,081.57$; and Gabon between $\$ 707,918,016.54$ and $\$ 2,334,677,687.39$. Paired t test on CEMAC's countries FDI net inflows shows that the flow of FDI inflows to Central Africa Republic, Chad, Congo, and Gabon has improved within the period of the analysis, which is not the case for Cameroon and Equatorial Guinea.

A final paired t test of FDI net inflows was run on all combined constituents of the CEMAC region, and the test revealed that FDI net inflows was not significant, with $\mathrm{t}(5)=.26$ and the $\mathrm{p}$ value $=.06$. The CEMAC's $\mathrm{p}$ value of the FDI net inflows was greater than the alpha, and the $t$ value was smaller than the critical value. Therefore, as a regional community, CEMAC's countries were collectively not performing well in terms of attracting and retaining foreign investments. Table 12 shows the results of each country's paired $t$ test for FDI net inflows based on the 2007-2017 trend analysis, including the $t$ statistic and the critical $t$ value. 
Table 2. Paired t Test summary results of foreign direct investment net inflows for all Central African Economic and Monetary Community (CEMAC) countries

\begin{tabular}{llllllll}
\hline & Cameroon & $\begin{array}{l}\text { Central Africa } \\
\text { Republic }\end{array}$ & Chad & $\begin{array}{l}\text { Congo } \\
\text { Republic }\end{array}$ & $\begin{array}{l}\text { Equatorial } \\
\text { Guinea }\end{array}$ & $\begin{array}{l}\text { CEMAC } \\
\text { Gabon }\end{array}$ \\
\hline Observation & 5.00 & 5.00 & 5.00 & 5.00 & 5.00 & 5.00 & 5.00 \\
\hline$d f$ & 4.00 & 4.00 & 4.00 & 4.00 & 4.00 & 4.00 & 4.00 \\
\hline$t$ critical two-tail & 2.776 & 2.776 & 2.776 & 2.776 & 2.776 & 2.776 & 2.776 \\
\hline$t$ statistic & $(1.46)$ & $(4.83)$ & $(4.92)$ & 4.58 & $(1.16)$ & 5.19 & 2.60 \\
\hline$p(T<=t)$ two-tail & 0.22 & $0.01^{*}$ & $0.01 *$ & $0.01 *$ & 0.31 & $0.01 *$ & 0.06 \\
\hline
\end{tabular}

Note. ${ }^{*} p \leq .05$ indicates statistical significance. Parentheses indicate a negative number. $d f=$ degree of freedom; $\bar{d}=$ sample mean; $t$ value measures the size of the difference relative to the variation in sample data; $p$ value is a number between 0 and 1 and interpreted in the following way: a small $\mathrm{p}$ value (typically $\leq 0.05$ ) indicates strong evidence against the null hypothesis, so the null hypothesis is rejected.

\section{Discussion and Implications}

This study found that FDI net inflows, GDP per capita, trade openness, total natural resource rents, political stability, and rule of law decreased over the period 2007-2017, while inflation rate and control for Corruption Perception Index increased over the same period. This means that FDI net inflow reduction may have a direct influence on host countries' productivity and long-term growth in CEMAC region. This can be observed that when terms of trade are rigid, investors are reluctant, or even limited, to having access to a CEMAC market, which limits the country's ability to attract MNCs with enough expertise to exploit natural resources.

The worsening rating of political stability and rule of law ratings can be a result of the ongoing civil war in member countries such as Cameroon during the fight against the Boko Haram terrorist group in the northern part of the country (Kelvin \& Ofir, 2010). Civil war has been contributing to keeping the political stability and the rule of law very low, among other factors such as the longevity of the sitting political leaders; the inadequacy of existing regulation to the economic environment; the disproportionate application of law among stakeholder; and the permanent risk of popular unrest in the country.

The findings draw implication that, so far, FDI has not been beneficial to regular citizens in the CEMAC region, for all countries collectively as well as individually. This contrasts with the work of Graham and Spaulding (2005) discussed in the literature review, which supported FDI inflows as beneficial for host countries. In the case of CEMAC, in which the economy is mainly natural-resource based, the fluctuating oil price can justify a gain of FDI net inflows in the region, but they are not high enough to offset deficiencies in other sectors. Disparities in oil rent redistribution and high level of corruption, in addition to the mismanagement of public funds coupled with unfair enforcement of existing laws can explain why FDI net inflows did not improve the GDP per capita. In fact, an improvement of the GDP per capita may have been a sign of the local economy taking advantage of the inflows of FDI.

A deterioration of living conditions is noticeable and is evidenced through a weakening GDP per capita value; thereby, weaker purchasing power for the CEMAC population residents. This seems to contradict the literature review in which the report of BAD supported a steady decline of poverty in the CEMAC region from 1960 to 2013 (BAD, 2018). In fact, the ongoing civil war in Central Africa Republic involving the government rebels from the Séléka coalition, and anti-Balaka militias (Kelvin \& Ofir, 2010) could justify the deterioration of living standards in CEMAC region. The researcher may then suggest that lack of or more FDI net inflow in the CEMAC region may not necessarily translate into an improvement of living standard.

Improvement of living standards may to certain extent relate to the type of FDI flowing in a country, as well as a set of strong regulations and other factors that contribute to fight poverty. Central African countries' substantial dependence on nonrenewable oil or crude oil and mineral resources could be also a factor since the prices have been decreasing for the period of consideration in this study. The crude oil prices have been at a record low since December 2012, from $\$ 91$ for one barrel to $\$ 59$ a barrel in December 2017 (Organization of Petroleum Exporting Countries, 2018). Currently, three CEMAC countries, Congo, Equatorial Guinea, and Gabon, are members of the Organization of Petroleum Exporting Countries. 
In fact, taking into consideration societal events in the region during the past 5 years until now, at the time of writing this study, political stability and risk of terrorism have been very high in the CEMAC region and contribute to destabilizing the region (Danziger, 2019; IMF, 2019; University of Central Arkansas, n.d.).

At the time the researchers concluded this research with direct implications to the CEMAC' region, it was important to reflect to the literature review about the control for corruption perception, which has deterred the regional economy. Dongmo (2006) revealed the growing corruption in the CEMAC has negatively affected economy growth and development. Therefore, the statistical significance of the paired test result of control for Corruption Perception Index in CEMAC suggests that corruption is a main damaging factor of the regional economy. Hence, this research sides with Okonjo-Iweala (2018) and Nantharath and Eungoo (2019) for strong institutions and management processes that will limit the ability of public agents to commit fraud or corruption.

\section{References}

African Development Bank (BAD). (2018). Macroeconomic developments and poverty, inequality, and employment: Managing forestry's potential. $\quad$ Retrieved from https://www.afdb.org/fileadmin/uploads/afdb/Documents/Publications/2018AEO/African-Economic-Outlook-2 018-Central-Africa.pdf

Aidt, T. S. (2003). Economic analysis of corruption: A survey. Economic Journal, 113, F633-F652. https://doi.org/10.1046/j.0013-0133.2003.00171.x

Alfaro, L. (2016). Gains from foreign direct investment: Macro and micro approaches. The World Bank Economic Review, 30(1), 2-15. https://doi.org/10.1093/wber/lhw007

Asiedu, E. (2013). Foreign direct investment, natural resources and institutions. Retrieved from https://www.theigc.org/wp-content/uploads/2014/09/Asiedu-2013-Working-Paper.pdf

Ata, A. Y., \& Arvas, M. A. (2011). Determinant of economic corruption: A cross-country data analysis. International Journal of Business and Social Science, 2(13). Retrieved from http://ijbssnet.com/journals/Vol._2_No._13_Special_Issue_July_2011/17.pdf

Avom, D., \& Ongo Nkoa, B. E. (2013). Why foreign direct investment goes towards Central Africa. Journal of Economics and Sustainable Development, 4(9), 9-17. Retrieved from https://www.iiste.org/Journals/index.php/JEDS/article/view/6474

Batassi, E., \& Smith, E. (2019). Politics: Gabon military seizes state broadcaster in coup attempt. Bloomberg. Retrieved from https://www.bloomberg.com/news/articles/2019-01-07/gabon-military-seizes-state-radio-in-apparent-coup-atte $\mathrm{mpt}$

Bayraktar, N. (2013). Foreign direct investment and investment climate. Paper presented at the International Conference on Applied Economics (ICOAE), Istanbul, Turkey.

Biswas, R. (2002). Determinants of foreign direct investment. Review of Development Economics, 6(3), 492-504. https://doi.org/10.1111/1467-9361.00169/pdf

Danziger, R. (2019). Confronting the challenges of migration in West and Central Africa. United Nations Africa Renewal. Retrieved from https://www.un.org/africarenewal/magazine/december-2018-march-2019/confronting-challenges-migration-wes t-and-central-africa

Dongmo, C. (2006). Envisioning a developmental and democratic approach to globalization in the Economic and Monetary Community of Central African States (CEMAC). Paper presented at the 50th Anniversary of the Graduate Program in Economic Development (GPED) Conference on Globalization and the Developing Countries. Nashville, TN. Retrieved from http://citeseerx.ist.psu.edu/viewdoc/download?doi=10.1.1.532.5108\&rep=rep1\&type=pdf

Farole, T., Staritz, C., \& Winkler, D. (2014). Conceptual framework. In T. Farole, \& D. Winkler (Eds.), Making foreign direct investment work for Sub-Saharan Africa: Local spillovers and competitiveness in global value chains (pp. 23-55). https://doi.org/10.1596/978-1-4648-0126-6_ch2

Freedom House. (2019). Freedom in the world 2019: Cameroon. Freedom House. Retrieved from https://freedomhouse.org/report/freedom-world/2019/cameroon 
Human Rights Watch. (2017). Equatorial Guinea events of 2017. Retrieved from https://www.hrw.org/world-report/2018/country-chapters/equatorial-guinea

Hussein, K. A. (2017). Analysis of the effectiveness of anticorruption legislation in developing countries: The impact on the national well-being of adopting nations. Doctoral dissertation, St. Mary's University of Minnesota, Minneapolis, MN. Retrieved from http://www2.smumn.edu/deptpages/tclibrary/search/dissertations/dba.php

International Monetary Fund. (2018). IMF executive board concludes annual discussions on CEMAC common policies, and common policies in support of member countries reform programs [Press release]. Retrieved from https://www.imf.org/en/News/Articles/2018/12/18/pr18478-imf-exc-brd-concl-annl-disc-cemac-common-polici es-and-com-pol-support-memb-cntry-rfrm-progr

International Monetary Fund. (2019). A regional approach to enhancing governance and reducing the potential for $\begin{array}{llllll}\text { corruption } & \text { (IMF Country Report No. 19/2). } & \text { Retrieved from }\end{array}$ https://www.imf.org/ /media/Files/Publications/CR/2019/cr1902.ashx

Kahai, S. K. (1999). Traditional and non-traditional determinants of foreign direct investment. Clute Institute. Retrieved from ttps://www.cluteinstitute.com/ojs/index.php/JABR/article/download/2194/2171

Kaufmann, D., \& Wei, S. J. (1999). Corruption in economic transition and development: Grease or sand?. Retrieved from https://www.unece.org/fileadmin/DAM/ead/sem/sem2001/papers/Wei.pdf

Kelvin, S. H. P., \& Ofir, D. (2010). Fighting corruption to save the environment: Cameroon's experience. Ambio: A Journal of the Human Environment, 39(4), 336-339. https://doi.org/10.1007/s13280-010-0053-0

Lebens, M. (2017). Free tuition and enrollment at Midwest state two-year colleges. Doctoral dissertation, St. Mary's University of Minnesota, Minneapolis, MN. Retrieved from http://www2.smumn.edu/deptpages/tclibrary/search/dissertations/dba.php

Méon, P. G., \& Sekkat, K. (2005). Does corruption grease or sand the wheels of growth?. Public Choice, 122(1), 69-97. https://doi.org/10.1007/s11127-005-3988-0

Moreira, S. B. (2009). The determinants of foreign direct investment. What is the evidence for Africa?. Poiesis, 2(1), 83-104. Retrieved from https://comum.rcaap.pt/bitstream/10400.26/4445/1/14_2009_POIESIS_paper.pdf

Morris, R., \& Aziz, A. (2011). Ease of doing business and FDI inflow to sub-Saharan Africa and Asian countries. Cross Cultural Management: An International Journal, 18(4), 400-411. https://doi.org/10.1108/13527601111179483

Ngongang, E. (2012). Foreign direct investment in regional integration: Comparative attractiveness in the CEMAC and UEMOA economic spaces. European Journal of Sustainable Development, 1(3), 419-444. https://doi.org/10.14207/ejsd.2012.v1n3p419

Okonjo-Iweala, N. (2018). Fighting corruption is dangerous: The story behind the headlines. MIT Press. Retrieved from https://mitpress.mit.edu/books/fighting-corruption-dangerous

Ongo Nkoa, E. B. (2013). Does foreign direct investment improve economic growth in CEMAC countries?. European Journal of Business \& Economics, 8(2), 43-49. https://doi.org/10.12955/ejbe.v8i2.407

Organization of Petroleum Exporting Countries. (2018, December). Present economic situation points to oil market imbalance over the coming months. Retrieved from https://www.opec.org/opec_web/static_files_project/media/downloads/publications/MR122008.pdf

Organization for Economic Cooperation and Development. (2008, June). The impact of foreign direct investment on wages and working conditions. OECD-ILO Conference on Corporate Social Responsibility Employment and Industrial Relations: Promoting Responsible Business Conduct in a Globalizing Economy, Paris, France. Retrieved from https://www.oecd.org/investment/mne/40848277.pdf

Rosenberg, T. (2012). Globalization. The New York Times. Retrieved from http://www.nytimes.com/2002/08/18/magazine/globalization.html

Shields, P. M., \& Rangarajan, N. (2013). A playbook for research methods: Integrating conceptual frameworks and project management. Stillwater, OK: New Forums Press.

Shleifer, A., Robert, W., \& Vishny, R. W. (1993). Corruption. The Quarterly Journal of Economics, 108(3), 599-617. https://doi.org/10.2307/2118402 
Silberman, J. M., Weiss, C., \& Dutz, M. (1996). Marshall Plan productivity assistance: A unique program of mass technology transfer and a precedent for the former Soviet Union. Technology in Society, 18(4), 443-460. https://doi.org/10.1016/S0160-791X(96)00023-1

$\mathrm{Su}, \mathrm{Y}$., \& Liu, Z. (2016). The impact of foreign direct investment and human capital on economic growth: Evidence from Chinese cities. China Economic Review, 37, 97-109. https://doi.org/10.1016/j.chieco.2015.12.007

United Nation Conference on Trade and Development. (2016). FDI recovery is unexpectedly strong, but lacks productivity impact. Global Investment Trends Monitor, 22, 1-8. Retrieved from https://unctad.org/en/PublicationsLibrary/webdiaeia2016d1_en.pdf

United Nations Conference on Trade and Development. (2017, June 7). Foreign direct investment to Africa fell by a moderate three per cent in 2016, says UN report [Press release]. Retrieved from http://unctad.org/en/pages/PressRelease.aspx?OriginalVersionID=408

University of Central Arkansas. (n.d.). Political science: 36. Central Africa Republic (1960-present). Retrieved from https://uca.edu/politicalscience/dadm-project/sub-saharan-africa-region/central-african-republic-1960-present/

World Bank Group. (2018a). Worldwide Governance Indicators (WGI). Retrieved from http://info.worldbank.org/governance/wgi/\#home

World Bank Group. (2018b). Poverty. Retrieved from https://www.worldbank.org/en/topic/poverty/overview

\section{Copyrights}

Copyright for this article is retained by the author(s), with first publication rights granted to the journal.

This is an open-access article distributed under the terms and conditions of the Creative Commons Attribution license (http://creativecommons.org/licenses/by/4.0/). 